\title{
Determination of enzymatic activities using a miniaturized system as a rapid method to assess soil quality
}

\author{
R. B oluda ${ }^{\mathrm{a}}, \mathrm{L}$. Roca-Pérez ${ }^{\mathrm{a}}, \mathrm{M}$. Iranzo ${ }^{\mathrm{b}}, \mathrm{C} \cdot \mathrm{Gil}^{\mathrm{c}}$ \& S. Mormeneo \\ ${ }^{a}$ Department of Plant Biology, Faculty of Pharmacy, University of València, Av Vicent Andrés i Estellés s/n, 46100 Burjassot, València \\ Spain, ${ }^{b}$ Department of Microbiology, Faculty of Pharmacy, University of València, Av Vicent Andrés i Estellés s/n, 46100 Burjassot, \\ València Spain, and ${ }^{\mathrm{c} S o i l}$ Science Department, University of Almería, Ctra. de Sacramento s/n, 04120 La Cañada Almería, Spain
}

\begin{abstract}
Summary
Soil quality determination requires the analysis of a number of soil attributes using different approaches. In recent years, one of the most promising approaches has been the determination of enzymatic activities. Generally, only a few enzymes have been analysed and related to other soil properties such as total carbon, nitrogen content or microbial biomass carbon. The aim of this work was to investigate the possible use of the API ZYM strip, a semi-quantitative miniaturized system that determines 19 enzymatic activities, to study soil quality. To this end, we tested the system in different soil types, including albic Arenosols, mollic Leptosols, rendzic Leptosols, haplic Leptosols and calcaric Regosols. Fresh samples were sieved through a 2-mm sieve in the field and soil extracts were prepared by mixing 2-20 g (depending on the soil horizon characteristics) from each sample with $2-20 \mathrm{ml}$ of sterile water. Next, $65-\mu 1$ aliquots of the supernatant extract were placed into each API ZYM microtube and were incubated at $37^{\circ} \mathrm{C}$ for 16 hours. Our results show important qualitative and quantitative differences among the different soil types studied, with soil characteristics and biological properties correlating with biochemical information. The results provide useful information not only to determine soil quality, but also to assess changes in the soil environment. As a whole, our results suggest that the use of the API ZYM system could prove most useful in soil environmental studies. Finally, some suggestions are presented, including modifications to the system that could improve its application in this field.
\end{abstract}

\section{Introduction}

Soil quality is a concept that either reflects the general environmental status or acts as a model of soil's capacity to function properly in the present and the future (Karlen et al., 1997). Soil quality indicators include a wide range of biological processes and functions, which occur in situ. Having defined the biological activity-related quality indicators (Blum, 1990; Salazar et al., 2011; Wallenius et al., 2011; Adrover et al., 2012), changes in soil quality must be reflected in the biological activities. It is accepted that indicators must be simple, easy to measure, quantitative, sensitive to changes and directly related to the basic ecological functions that soil performs (Yu et al., 1998; Cornforth, 1999; Macci et al., 2012; Thavamani et al., 2012). As the origin of most soil enzymes is microbial, these activities have been proposed as appropriate soil quality indicators (García-Ruíz et al., 2008; Trasar-Cepeda et al., 2008). In addition, enzymatic activities have

Correspondence: R. Boluda. E-mail: boluda@uv.es

Received 23 February 2013; revised version accepted 12 October 2013 been used, for example in assessing the influence of plant cover on soil microbial activities in Mediterranean ecosystem soils at different seral stages (Fioretto et al., 2009), studying the effects of simulated acid rain on soil enzyme activities (Wang et al., 2010), evaluating soil biological activity and phytotoxicity to garden cress (Lepidium sativum L.) in a soil polluted with diesel fuel (Serrano et al., 2009), or determining the effects of two acid resin deposits on soil microbiota (Pérez-de-Mora et al., 2008). Such studies have made it possible to find correlations between soil biochemical and microbiological variables under different conditions.

In order to review diagnostic soil quality criteria, a minimum number of soil attributes is required (Doran et al., 1996). Soil enzyme activities are commonly used as soil pollution indicators of soil quality because of their sensitivity to environmental changes and because they can be easily determined in a costeffective way (Wallenius et al., 2011; Thavamani et al., 2012).

The present report addresses the study of an array of enzymes in soil. A novel approach based on the API ZYM (BioMerieux) kit has been used to determine enzyme profiles in soils at 
Table 1 Use, formation factors and morphology of soils studied

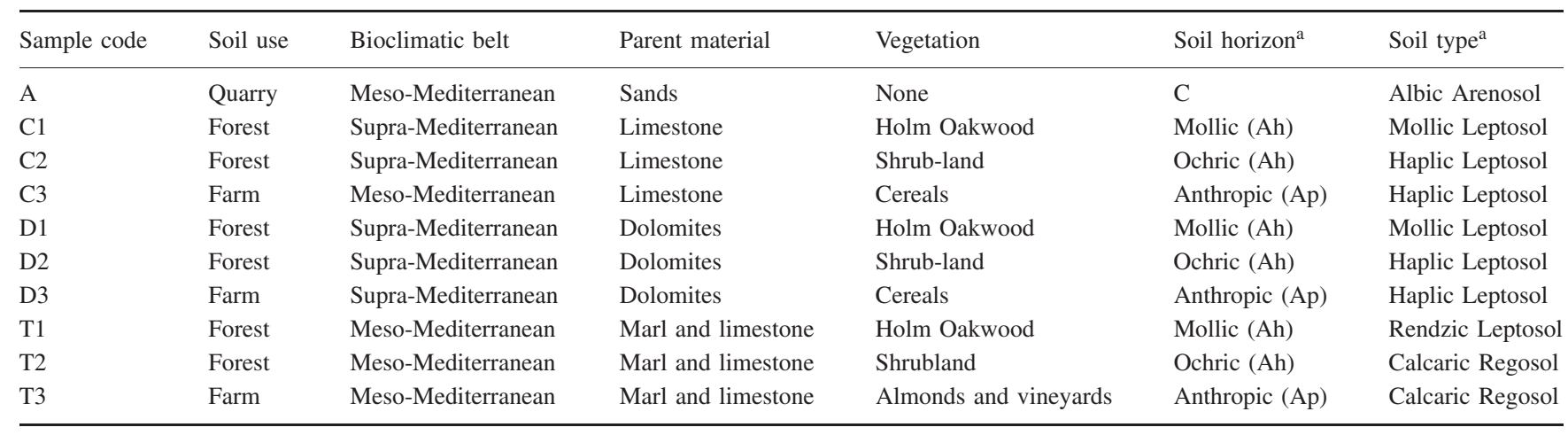

${ }^{\mathrm{a}} \mathrm{FAO}(2006)$.

Table 2 Some properties of the soils studied

\begin{tabular}{|c|c|c|c|c|c|c|c|c|c|c|c|}
\hline Sample & $\begin{array}{l}\mathrm{pH} \\
\left(\mathrm{H}_{2} \mathrm{O}\right)\end{array}$ & $\begin{array}{l}\mathrm{CaCO}_{3}{ }^{\mathrm{a}} \\
/ \mathrm{g} \mathrm{kg}^{-1}\end{array}$ & $\begin{array}{l}\text { Sand }^{a} \\
/ \%\end{array}$ & $\begin{array}{l}\text { Silt } \\
/ \%\end{array}$ & $\begin{array}{l}\text { Clay }^{\mathrm{a}} \\
/ \%\end{array}$ & $\begin{array}{l}\mathrm{EC} \\
/ \mathrm{dS} \mathrm{m}^{-1}\end{array}$ & $\begin{array}{l}\text { Texture } \\
\text { USDA }\end{array}$ & $\begin{array}{l}\mathrm{SOM}^{\mathrm{a}} \\
/ \%\end{array}$ & $\begin{array}{l}\mathrm{N}^{\mathrm{a}} \\
/ \%\end{array}$ & $\begin{array}{l}\text { Respiration } \\
\text { rate }^{\mathrm{a}, \mathrm{b}} \\
/ \mathrm{mg} \mathrm{O}_{2} \mathrm{~kg}^{-1}\end{array}$ & $\begin{array}{l}\text { Microbial } \\
\text { biomass } \mathrm{C}^{\mathrm{a}} \\
/ \mathrm{mg} \mathrm{kg}^{-1}\end{array}$ \\
\hline $\mathrm{C} 1$ & $7.28 \pm 0.01$ & $16 \pm 1$ & $20 \pm 1$ & $36 \pm 2$ & $44 \pm 3$ & $0.23 \pm 0.01$ & Clay & $17.2 \pm 1.7$ & $0.71 \pm 0.03$ & $2200 \pm 220$ & $2419 \pm 311$ \\
\hline $\mathrm{C} 2$ & $8.09 \pm 0.01$ & $66 \pm 4$ & $17 \pm 1$ & $49 \pm 1$ & $34 \pm 2$ & $0.15 \pm 0.01$ & Silty clay loam & $8.5 \pm 1.2$ & $0.47 \pm 0.02$ & $1019 \pm 148$ & $1374 \pm 234$ \\
\hline $\mathrm{C} 3$ & $8.40 \pm 0.05$ & $389 \pm 30$ & $24 \pm 1$ & $45 \pm 0$ & $31 \pm 1$ & $0.15 \pm 0.00$ & Clay loam & $2.0 \pm 0.1$ & $0.18 \pm 0.01$ & $442 \pm 25$ & $534 \pm 75$ \\
\hline D3 & $8.41 \pm 0.01$ & $465 \pm 22$ & $20 \pm 2$ & $43 \pm 3$ & $37 \pm 2$ & $0.11 \pm 0.00$ & Clay loam & $2.2 \pm 0.2$ & $0.20 \pm 0.01$ & $489 \pm 106$ & $446 \pm 49$ \\
\hline $\mathrm{T} 1$ & $7.81 \pm 0.01$ & $87 \pm 0$ & $32 \pm 1$ & $20 \pm 0$ & $48 \pm 0$ & $0.22 \pm 0.00$ & Clay & $11.9 \pm 0.4$ & $0.49 \pm 0.04$ & $2417 \pm 268$ & $1407 \pm 315$ \\
\hline $\mathrm{T} 2$ & $8.40 \pm 0.13$ & $161 \pm 1$ & $31 \pm 5$ & $30 \pm 1$ & $39 \pm 5$ & $0.13 \pm 0.00$ & Clay loam & $4.1 \pm 0.2$ & $0.21 \pm 0.02$ & $945 \pm 53$ & $494 \pm 80$ \\
\hline $\mathrm{T} 3$ & $8.37 \pm 0.01$ & $170 \pm 1$ & $29 \pm 0$ & $26 \pm 1$ & $45 \pm 1$ & $0.15 \pm 0.00$ & Clay & $2.8 \pm 0.3$ & $0.19 \pm 0.01$ & $557 \pm 133$ & $399 \pm 220$ \\
\hline
\end{tabular}

${ }^{\mathrm{a}}$ Dry mass.

${ }^{b}$ Respiration rate, $\mathrm{O}_{2}$ uptake by soil microorganisms after 10 days of incubation.

EC, electrical conductivity; SOM, soil organic matter; nd, not detected.

Mean \pm standard deviation; $n=3$.

different degradation stages. API ZYM is a semi-quantitative miniaturized system designed to perform a systematic rapid study of 19 enzymatic reactions. It consists of a series of micro-cupules containing dehydrated chromogenic substrates of 19 different enzymes and one control. We hypothesized that this miniaturized system could be useful to study changes in soil quality, and the specific objective is to optimize a semi-quantitative micro-method test to determine the enzymatic activities in several soil subunits at three seral vegetational stages (forest, shrub-land and managed land) in a Mediterranean environment.

\section{Material and methods}

\section{Study sites and soil sampling}

A rural area in the Valencian Community (east Spain), which includes forest soils and soils affected by both deforestation processes and agricultural uses, was chosen. The sampling points in this study area were selected on the basis of identified soil formation factors, and soils were classified by their characteristic properties according to the FAO (2006) classification system
(Tables 1, 2). Sampled soils are representative of the Mediterranean region in the Iberian Peninsula and correspond to the following soil subunits (FAO): albic Arenosol (A), mollic Leptosols (C1, D1), rendzic Leptosols (T1), haplic Leptosols (C2, C3, D2, D3) and calcaric Regosols (T2, T3). In the study area, the climate is Mediterranean with supra- and meso-Mediterranean bioclimates. Systematic sampling between spring and summer was carried out as follows (in a specific area, units were selected in terms of parent material, vegetation type and soil use). Three subunits were sampled in each unit: natural vegetation (Holm Oakwood, Quercus ilex sp. rotundifolia L.) (C1, D1, T1), vegetation degraded to shrub-land (C2, D2, T2), and cereals (C3, D3), almond plantations and vineyards (T3). Additionally, a sample was taken from quarry sediments of arid, albic Arenosols in order to obtain a control with very small biological activity (A). Sampling was conducted in two plots per sampling unit; a small soil pit was dug on the surface horizon, measuring approximately $30 \times 30 \times 15 \mathrm{~cm}$ to take a representative sample from this volume of soil. Within each plot, three or four subsamples were taken from a 0 to $15-\mathrm{cm}$ soil depth, and a total mass of $5 \mathrm{~kg}$ was obtained. Subsamples were 
taken at a distance of approximately $50 \mathrm{~m}$ from each other following zigzag-shaped transects. In addition, a $200-\mathrm{cm}^{3}$ container was filled with fresh soil sample sieved with a $2-\mathrm{mm}$ sieve in the field for the immediate determination of enzymatic activities. These containers were placed in a portable refrigeration unit to be transported to the laboratory, where they were kept in a chamber at $4^{\circ} \mathrm{C}$ for no more than 48 hours until analysed.

\section{Soil physical, chemical and biological analyses}

Some physical, chemical and biological soil properties were measured. Aspects of the biological and biochemical activity of soils were studied by determining respiration rate, microbial biomass carbon and enzymatic activities. Samples were pretreated in accordance with the ISO (1994a) procedure. $\mathrm{pH}$ was measured in a soil:water suspension of 1:5 (v/v) with a GLP Crison (Crison, Barcelona, Spain) $\mathrm{pH}$ meter (ISO, 1994b). Electrical conductivity (EC) was determined in a water extract at a ratio of 1:5 (w/v) with a PC 2700 conductimeter (EUTECH Instruments, Singapore) (ISO, 1994c). Particle size was determined by the Bouyoucos densimeter method (Day, 1965). Carbonates were determined by gasometry by adding excess $6 \mathrm{~m}$ hydrochloric acid to the sample and by measuring the volume of the carbon dioxide produced with a Scheibler apparatus (ISO, 1995). Soil organic matter (SOM) was measured by oxidation with potassium dichromate in the presence of sulphuric acid and by subsequent titration with ammonium ferrous sulphate (Walkley \& Black, 1934). Total N was measured by an elemental Auto-Analyzer EA 1110 CNHS (CE Instruments, Milan,italy) with heat treatment and a temperature of at least $900^{\circ} \mathrm{C}$ in the presence of oxygen. OxiTopOC110 respirometers (Wissenschaftlich-Technische, Wersktätten, Weilheim) were used to determine the respiration rates of soil biological activity; the $\mathrm{CO}_{2}$ emitted was neutralized by sodium hydroxide, and the reduction of the pressure thus generated in the hermetically sealed container was detected by a piezoelectric sensor (Platen \& Wirtz, 1999); soil samples were incubated at $20^{\circ} \mathrm{C}$ over 5 days. Microbial biomass carbon was determined by the induced respiration method. This method is based on the fact that when increasing amounts of glucose are provided to the soil the maximum rate of respiration is reached during the first hour, so active microbial biomass is determined for this defined maximum initial respiration rate of the soil (ISO, 1997). All the analyses were made in triplicate.

\section{The API ZYM system assay}

Soil extracts were prepared by mixing $2-20 \mathrm{~g}$ of each homogenized sample with $2-20 \mathrm{ml}$ of sterile water. The solution was shaken for 20 minutes at $23 \pm 2^{\circ} \mathrm{C}$ and centrifuged for 5 minutes at $2000 \mathrm{~g}$. The supernatant was filtered with $2.5-\mu \mathrm{m}$ filters and used for the enzyme analysis. API ZYM strips (BioMerieux, Marcy l'Etoile, France) consist of 20 micro-cupules containing dehydrated chromogenic substrates of 19 different enzymes. The first micro-cupule served as a control. The enzymes determined in each tube are listed in Table 3 . The kit has been successfully used to study the enzymatic activities of microorganisms and cell suspensions and also during manure composting (Jain et al., 1991; Bidochka et al., 1999; Khan et al., 1999; Garcia-Martos et al., 2001; Tiquia et al., 2001; Tiquia, 2002). Aliquots (65 $\mu \mathrm{l})$ of the supernatant extract were placed in all the micro-cupules. API ZYM strips were then covered and incubated aerobically at different temperatures and times. After incubation, $30 \mu \mathrm{l}$ of each reagent (ZYM A and ZYM B; BioMerieux) were added to all the micro-cupules to develop chromogenic substrates. After 5 minutes a numerical value from 0 to 5 was assigned to each reaction according to the colour chart provided by the manufacturer. For the purposes of this study, only those colours showing an index of 2 or more were recorded as positive and, according to Tiquia (2002), were reported as follows: low intensity (1), moderate intensity (2-3) and high intensity (4-5).

For the purposes of optimizing the API system response and improving the effectiveness of this test, the effect of the following aspects was established: soil use, sample processing, soil:extract ratio (w/v), amount of soil, incubation temperature and incubation time. The first step entailed following the procedure proposed by Tiquia (2002) with forest soil (T1) and with soil in which vines were growing (T3) by using fresh samples sieved in the field and an air-dried sample to estimate the degree of test response in soils with various degradation stages undergoing different processing. The second step consisted of conducting trials with the extracts taken from the different soil:water ratios $(\mathrm{w} / \mathrm{v})$ of 1:10 (Tiquia, 2002), 1:5, 1:2.5, and $1: 1$. The third step involved studying the effect of incubation temperature $\left(4,20\right.$ and $\left.37^{\circ} \mathrm{C}\right)$, incubation time (4, 8, 16 and 24 hours) and amount of sample (2, 5 and $10 \mathrm{~g})$. The test conditions that produced the greatest intensity and the largest number of enzymatic activities were selected and used to assess both the enzymatic activity and quality of the different sampled soils. All the analyses were made in triplicate.

\section{Statistical analysis}

The values provided in the tables are reported as the mean \pm standard deviation of three laboratory measures taken with each soil sample. Data were analysed with the SPSS 21 software package. Spearman's coefficient was used to calculate the linear correlations among all the study variables and a hierarchical test was carried out. In addition, variables without any significant correlation were eliminated and Bonferroni's method was used to avoid the overall risk of Type I error not exceeding 0.05 .

\section{Results}

\section{Soil properties}

The main soil properties are presented in Table 2. Soil morphology is influenced by soil formation factors, including human activities. Thus, soil profile is characterized as O-Ah-R for mollic Leptosols and rendzic Leptosols, Ah-R for haplic Leptosols and Ap-C for calcaric Regosols. In general, the soils had similar textures and clay contents. The $\mathrm{pH}$ was less in mollic and rendzic Leptosols 
Table 3 Relative activity of extracellular enzymes extracted from forest rendzic Leptosol (T1) and farming calcaric Regosol (T3) at different soil extract dilutions $(w / v)$

\begin{tabular}{|c|c|c|c|c|c|c|c|c|c|c|c|c|c|c|}
\hline Enzyme & \multicolumn{4}{|l|}{$\mathrm{T} 1^{\mathrm{a}}$} & \multicolumn{3}{|l|}{$\mathrm{T} 1^{\mathrm{b}}$} & \multicolumn{4}{|l|}{$\mathrm{T}^{\mathrm{a}}$} & \multicolumn{3}{|l|}{$\mathrm{T}^{\mathrm{b}}$} \\
\hline Alkaline phosphatase & 1 & 2 & 3 & 5 & 1 & 1 & 1 & 0 & 0 & 0 & 3 & 0 & 0 & 0 \\
\hline Acid phosphatase & 1 & 4 & 4 & 5 & 1 & 3 & 1 & 0 & 1 & 1 & 0 & 0 & 0 & 0 \\
\hline Phosphohydrolase & 1 & 2 & 3 & 5 & 1 & 2 & 3 & 0 & 1 & 1 & 2 & 0 & 1 & 1 \\
\hline \multicolumn{15}{|l|}{ Esterases } \\
\hline Lipase & 0 & 0 & 0 & 0 & 0 & 0 & 0 & 0 & 0 & 0 & 0 & 0 & 0 & 0 \\
\hline Lipase-esterase & 1 & 1 & 2 & 4 & 1 & 1 & 1 & 0 & 0 & 0 & 3 & 0 & 0 & 0 \\
\hline \multicolumn{15}{|l|}{ Amino-peptidases } \\
\hline Leucine arylamidase & 0 & 1 & 2 & 5 & 0 & 1 & 2 & 0 & 0 & 0 & 0 & 0 & 0 & 0 \\
\hline Valine arylamidase & 0 & 0 & 0 & 1 & 0 & 1 & 0 & 0 & 0 & 0 & 0 & 0 & 0 & 0 \\
\hline \multicolumn{15}{|l|}{ Glycosyl hydrolases } \\
\hline$\alpha$-Galactosidase & 0 & 0 & 0 & 4 & 0 & 0 & 0 & 0 & 0 & 0 & 0 & 0 & 0 & 0 \\
\hline$\beta$-Galactosidase & 0 & 0 & 2 & 3 & 0 & 0 & 0 & 0 & 0 & 0 & 1 & 0 & 0 & 0 \\
\hline$\beta$-Glucoronidase & 0 & 0 & 1 & 2 & 0 & 0 & 0 & 0 & 0 & 0 & 0 & 0 & 0 & 0 \\
\hline$\alpha$-Glucosidase & 0 & 0 & 0 & 0 & 0 & 0 & 0 & 0 & 0 & 0 & 0 & 0 & 0 & 0 \\
\hline$\beta$-Glucosidase & 0 & 0 & 0 & 0 & 0 & 0 & 0 & 0 & 0 & 0 & 0 & 0 & 0 & 0 \\
\hline $\mathrm{N}$-acetyl- $\beta$-glucosaminidase & 0 & 2 & 3 & 4 & 0 & 0 & 0 & 0 & 0 & 0 & 0 & 0 & 0 & 0 \\
\hline$\alpha$-Mannosidase & 0 & 0 & 0 & 0 & 0 & 0 & 0 & 0 & 0 & 0 & 0 & 0 & 0 & 0 \\
\hline$\alpha$-Fucosidase & 0 & 0 & 1 & 1 & 0 & 0 & 0 & 0 & 0 & 0 & 1 & 0 & 0 & 0 \\
\hline
\end{tabular}

${ }^{a}$ Determinations made in fresh soil.

${ }^{\mathrm{b}}$ Determinations made in air-dried soil.

API ZYM system was incubated for 4 hours at $37^{\circ} \mathrm{C}$.

The values indicate: 0 , no activity; 1 , low-intensity activity; $2-3$, moderate-intensity activity; $4-5$, high-intensity activity.

while EC was greater than in haplic Leptosols and calcaric Regosols; this difference is related to the content of organic matter and carbonates of these soils. Carbonates, SOM, N, respiration rates and microbial biomass $\mathrm{C}$ content differed considerably with the various different serial vegetation stages. Soil texture ranged from silty-clay loam to silty clay, soil $\mathrm{pH}$ from neutral to slightly basic, carbonate content from moderate $\left(10-150 \mathrm{~g} \mathrm{~kg}^{-1}\right)$ to large ( $>150 \mathrm{~g} \mathrm{~kg}^{-1}$ ), and organic matter content was $>4 \%$ except for those soils with an Ap horizon (cultivated soils). Respiration rates and biomass $\mathrm{C}$ varied with vegetation and land use. The SOM, $\mathrm{N}$ and oxygen consumption rates in mollic and rendzic Leptosols varied from 11.9 to $20.9 \%, 0.49$ to $0.89 \%$ and from 2200 to $3033 \mathrm{mg} \mathrm{O}_{2} \mathrm{~kg}^{-1}$ dry soil, respectively. Respiration rate, microbial biomass-C, $\mathrm{N}$ and SOM was significantly less in the anthropic horizon (Ap) from agricultural soils (Table 2).

\section{Determining optimal conditions for the API ZYM system}

In order to define operational conditions for the method, the forest and farm soils were used before or after being air-dried. Because there was no background information, to provide an indication we started with the extract dilution of 1:10, as reported for compost by Tiquia et al. (2001) and Tiquia (2002). As Table 3 shows, only small activity rates of phosphatases and esterases were detected at this dilution of 1:10 and all the positive activities increased when the proportion of soil was increased. Quantitatively, there were large activities of phosphatases, esterase, lipase-esterase, leucine arylamidase, $\alpha$ - and $\beta$-galactosidase and $\mathrm{N}$-acetyl- $\beta$ glucosaminidase in fresh forest soil at the 1:1 dilution, while only phosphatases exhibited moderate or small activity in fresh farm soil and esterases had small activities in fresh farm soil. These results clearly reveal both qualitative and quantitative differences in enzyme activities between forest and farm soils. Moreover, the enzyme levels in both soils were drastically reduced when airdried soils were used, and practically no enzyme activities were detected in farm soils.

The API system was developed for the analysis of clinical samples by means of incubation for 4 hours at $37^{\circ} \mathrm{C}$. Since the intention here was to use the micro-test to analyse soil enzymatic activities, the effects of incubation temperature $(4,20$ and $\left.37^{\circ} \mathrm{C}\right)$, incubation time $(4,8,16$ and 24 hours) and amount of soil $(2,5$ and $10 \mathrm{~g})$ to be used to obtain the $1: 1(\mathrm{w} / \mathrm{v})$ 
Table 4 Relative activity of extracellular enzymes extracted from forest soils at different conditions

\begin{tabular}{|c|c|c|c|c|c|c|c|c|c|c|c|}
\hline \multirow[b]{2}{*}{ Enzyme } & \multicolumn{3}{|c|}{$\begin{array}{l}\text { Temperature } \\
/{ }^{\circ} \mathrm{C}\end{array}$} & \multicolumn{4}{|c|}{$\begin{array}{l}\text { Incubation } \\
\text { time }^{\text {b } / \text { hour }}\end{array}$} & \multicolumn{4}{|c|}{$\begin{array}{l}\text { Mass } \\
\text { variation }^{\mathrm{c}} / \mathrm{g}\end{array}$} \\
\hline & 4 & 20 & 37 & 4 & 8 & 16 & 24 & 2 & 5 & 10 & $10^{\mathrm{d}}$ \\
\hline \multicolumn{12}{|l|}{ Phosphatases } \\
\hline Alkaline phosphatase & 5 & 5 & 5 & 5 & 5 & 5 & 5 & 3 & 4 & 4 & 5 \\
\hline Acid phosphatase & 5 & 5 & 5 & 5 & 5 & 5 & 5 & 4 & 4 & 4 & 5 \\
\hline Phosphohydrolase & 3 & 5 & 5 & 5 & 5 & 5 & 5 & 3 & 3 & 3 & 5 \\
\hline \multicolumn{12}{|l|}{ Esterases } \\
\hline Esterase & 0 & 3 & 5 & 4 & 4 & 5 & 5 & 5 & 5 & 4 & 5 \\
\hline Lipase & 0 & 0 & 0 & 0 & 0 & 0 & 0 & 0 & 0 & 0 & 0 \\
\hline Lipase-esterase & 1 & 3 & 4 & 2 & 2 & 5 & 5 & 2 & 0 & 0 & 5 \\
\hline \multicolumn{12}{|l|}{ Amino-peptidases } \\
\hline Leucine arylamidase & 5 & 5 & 5 & 5 & 5 & 5 & 5 & 3 & 4 & 4 & 5 \\
\hline Valine arylamidase & 0 & 1 & 2 & 0 & 1 & 1 & 2 & 0 & 0 & 0 & 2 \\
\hline Cystine arylamidase & 0 & 0 & 1 & 0 & 0 & 1 & 1 & 0 & 0 & 0 & 1 \\
\hline \multicolumn{12}{|l|}{ Proteases } \\
\hline Trypsin & 1 & 0 & 0 & 0 & 0 & 0 & 0 & 0 & 0 & 0 & 0 \\
\hline$\alpha$-Chymotrypsin & 1 & 0 & 0 & 0 & 0 & 1 & 1 & 0 & 0 & 0 & 0 \\
\hline \multicolumn{12}{|l|}{ Glycosyl hydrolases } \\
\hline$\alpha$-Galactosidase & 0 & 2 & 5 & 3 & 3 & 5 & 5 & 0 & 0 & 0 & 3 \\
\hline$\beta$-Galactosidase & 1 & 2 & 5 & 3 & 3 & 4 & 5 & 2 & 1 & 2 & 3 \\
\hline$\beta$-Glucoronidase & 0 & 1 & 2 & 2 & 2 & 2 & 3 & 2 & 0 & 0 & 0 \\
\hline$\alpha$-Glucosidase & 1 & 1 & 1 & 1 & 1 & 1 & 1 & 0 & 0 & 0 & 1 \\
\hline$\beta$-Glucosidase & 0 & 1 & 1 & 2 & 1 & 1 & 1 & 1 & 0 & 0 & 4 \\
\hline $\begin{array}{l}\mathrm{N} \text {-acetyl- } \beta \text { - } \\
\quad \text { glucosaminidase }\end{array}$ & 0 & 1 & 4 & 4 & 4 & 4 & 4 & 2 & 1 & 2 & 4 \\
\hline$\alpha$-Mannosidase & 1 & 0 & 0 & 1 & 1 & 0 & 1 & 0 & 0 & 0 & 0 \\
\hline$\alpha$-Fucosidase & 1 & 1 & 1 & 1 & 2 & 2 & 2 & 1 & 0 & 0 & 0 \\
\hline
\end{tabular}

${ }^{\mathrm{a}}$ Forest mollic Leptosol (D1). Soil:extract 1:1 (w/v), $2 \mathrm{~g}$, incubation time 16 hours.

${ }^{b}$ Forest mollic Leptosol (D1). Soil:extract 1:1(w/v), $2 \mathrm{~g}$, temperature of incubation $37^{\circ} \mathrm{C}$.

${ }^{\mathrm{c}}$ Forest rendzic Leptosol (T1). Soil:extract 1:2.5 (w/v), incubation time 4 hours, temperature of incubation $37^{\circ} \mathrm{C}$.

${ }^{\mathrm{d}}$ Forest mollic Leptosol (D1). Soil:extract 1:1 (w/v), incubation time 16hours, temperature of incubation $37^{\circ} \mathrm{C}$.

The determinations were made on fresh soil. The values indicate: 0 , no activity; 1 , low-intensity activity; $2-3$, moderate-intensity activity; $4-5$, high-intensity activity.

extract were studied. In this case, D1-soil was used to obtain new information for other better quality soils (Table 4). Microtest incubation temperatures between 20 and $37^{\circ} \mathrm{C}$ showed no differences for activity of phosphatases and amino-peptidases. However, the greater the incubation temperature became, the greater the esterase and glycosyl hydrolase activities. The effect of incubation temperature was more marked at $4{ }^{\circ} \mathrm{C}$, at which esterases, valine arylamidase, cistine arylamidase and glycosyl hydrolases were not detected. The effect of incubation time on the relative enzymatic activity was not important and few variations were noted for lipase-esterase and galactosidases, when the incubation time was increased from 8 to 16 or to 24 hours.

Table 3 presents the results of the experiment with the rendzic Leptosol (forest soil-T1) and the calcaric Regosol (farm soilT3), where considerable differences were found. In quantitative terms, the activities in both soils were always greater in forest soils, which was the case for phosphatases, esterase, lipaseesterase, leucine arylamidase and several glycosyl hydrolases.
Table 5 Relative activity of extracellular enzymes extracted from different soils and land uses

\begin{tabular}{|c|c|c|c|c|c|c|c|c|c|c|}
\hline \multirow[b]{2}{*}{ Enzyme $^{b}$} & \multicolumn{10}{|c|}{ Soil type and land use $\mathrm{a}^{\mathrm{a}}$} \\
\hline & A & $\mathrm{C} 1$ & $\mathrm{C} 2$ & $\mathrm{C} 3$ & D1 & D2 & D3 & $\mathrm{T} 1$ & $\mathrm{~T} 2$ & $\mathrm{~T} 3$ \\
\hline \multicolumn{11}{|l|}{ Phosphatases } \\
\hline Alkaline phosphatase & 0 & 5 & 4 & 1 & 5 & 3 & 1 & 5 & 3 & 3 \\
\hline Acid phosphatase & 1 & 5 & 4 & 1 & 5 & 2 & 1 & 5 & 1 & 0 \\
\hline Phosphohydrolase & n.d. & 5 & 2 & 1 & 5 & 2 & 2 & 5 & 2 & 2 \\
\hline \multicolumn{11}{|l|}{ Esterases } \\
\hline Esterase & 0 & 5 & 3 & 1 & 5 & 1 & 0 & 5 & 1 & 2 \\
\hline Lipase & 0 & 1 & 0 & 0 & 0 & 0 & 0 & 0 & 0 & 0 \\
\hline Lipase-esterase & 0 & 5 & 4 & 1 & 4 & 1 & 0 & 4 & 1 & 3 \\
\hline \multicolumn{11}{|l|}{ Amino-peptidases } \\
\hline Leucine arylamidase & 0 & 5 & 3 & 0 & 5 & 2 & 0 & 5 & 0 & 0 \\
\hline Valine arylamidase & 0 & 2 & 1 & 1 & 2 & 1 & 1 & 1 & 0 & 0 \\
\hline Cystine arylamidase & 0 & 1 & 0 & 0 & 1 & 0 & 0 & 1 & 0 & 0 \\
\hline \multicolumn{11}{|l|}{ Proteases } \\
\hline Trypsin & 0 & 0 & 0 & 0 & 0 & 0 & 0 & 0 & 0 & 0 \\
\hline$\alpha$-Chymotrypsin & 0 & 0 & 0 & 0 & 0 & 0 & 0 & 0 & 0 & 0 \\
\hline \multicolumn{11}{|l|}{ Glycosyl hydrolases } \\
\hline$\alpha$-Galactosidase & 0 & 5 & 0 & 0 & 5 & 0 & 0 & 4 & 0 & 1 \\
\hline$\beta$-Galactosidase & 0 & 5 & 0 & 0 & 5 & 0 & 1 & 3 & 1 & 0 \\
\hline$\beta$-Glucoronidase & 0 & 4 & 0 & 0 & 2 & 0 & 0 & 2 & 0 & 0 \\
\hline$\alpha$-Glucosidase & 0 & 3 & 0 & 0 & 1 & 0 & 0 & 0 & 0 & 0 \\
\hline$\beta$-Glucosidase & 0 & 5 & 1 & 0 & 1 & 1 & 0 & 0 & 2 & 0 \\
\hline $\begin{array}{l}\mathrm{N} \text {-acetyl- } \beta \text { - } \\
\text { glucosaminidase }\end{array}$ & 0 & 5 & 3 & 0 & 4 & 0 & 0 & 4 & 0 & 0 \\
\hline$\alpha$-Mannosidase & 0 & 1 & 0 & 0 & 0 & 0 & 0 & 0 & 0 & 0 \\
\hline$\alpha$-Fucosidase & 0 & 2 & 0 & 0 & 1 & 0 & 0 & 1 & 0 & 1 \\
\hline
\end{tabular}

aA, albic Arenosol; C1 and D1, mollic Leptosols; T1, rendzic Leptosol; T2 and T3, calcaric Regosols; D2, C2, D3 and C3, haplic Leptosols; 1, forest; 2, shrub-land; 3, farm.

${ }^{\mathrm{b}}$ API ZYM system was incubated for 16 hours at $37^{\circ} \mathrm{C}$. No reaction (value of 0), reactions of low intensity (value of 1), moderate intensity (values of 2-3), and high intensity (values of 4-5).

n.d., not determined.

Furthermore, the results provided in Table 3 are similar to those obtained with the other soils used to analyse the various conditions in which the API system can be used (Table 4).

\section{Assessing the API micro-test to study soil quality}

The information derived from the previous test allowed us to use a wider range of enzymatic activities, which could be easily detected to assess the quality of the different soils. These optimal conditions for their extraction were: a fresh sample sieved through a 2-mm sieve in the field, an extract at $1: 1 \mathrm{w} / \mathrm{v}$ with $2 \mathrm{~g}$ of sample, an incubation temperature of $37^{\circ} \mathrm{C}$ and an incubation time of 16 hour. The results for the activities determined after this process are provided in Table 5 .

As expected, the sample corresponding to the C-horizon of albic Arenosol displayed no biological or biochemical activity. Among the 19 enzymes tested, the activities of lipase, cystine aryl-amidase, trypsin, $\alpha$-chymotrypsin and $\alpha$-mannosidase were not detected in any of the soil samples. Alkaline phosphatase, acid phosphatase, phosphohydrolase, esterase, lipase-esterase, leucine 
arylamidase, $\alpha$-galactosidase, $\beta$-galactosidase, $\beta$-glucoronidase, $\beta$-glucosidase and $\mathrm{N}$-acetyl- $\beta$-glucosaminidase had large activities and were the most abundant enzymes in the mollic Leptosols C1D1 and rendzic Leptosols T1 soils. Only alkaline phosphatase, phosphohydrolase, esterase and lipase-esterase were detected at low-moderate rates in the farm soils.

Soils under forest vegetation (Holm Oakwood) had greater enzyme activities compared with soils under other management types (for example farm soils C3-D3-T3) or under other conditions (shrubland soils C2-D2-T2), in agreement with other authors (Fioretto et al., 2009; Floch et al., 2009). The soils with intense enzymatic activity and more active enzymes were mollic Leptosols on limestone and those in Holm oakwoods in the supraMediterranean bioclimatic belt (C1): except for a few cases, D1 samples had similar activities to those of C1. Glycosyl hydrolases, such as $\alpha$-glucosidase, $\beta$-glucosidase and $\alpha$-manosidase, were not active in rendzic Leptosol on limestone and in Holm oakwoods in the meso-Mediterranean bioclimatic belt (T1), possibly indicating the influence of bioclimate on edaphic microbiota activity. In general, the haplic Leptosols and calcaric Regosols used for agriculture (C3, D3 and T3) had small enzymatic activity rates.

\section{Correlations between soil variables}

The correlation matrix results with Bonferroni's adjustments are provided in Table 6. Large correlation coefficients $(r>0.910$, $P<0.05)$ were obtained, and close relationships were found between $\mathrm{pH}$ and SOM, SOM and $\mathrm{N}$ content, SOM and respiration rate, $\mathrm{N}$ and respiration rate and $\mathrm{N}$ and microbial biomass $\mathrm{C}$. These soil properties were also significantly correlated with some enzymatic activities. Generally, enzymatic activities decreased with decreasing $\mathrm{pH}$ and increased with $\mathrm{SOM}, \mathrm{N}$, respiration rate and microbial biomass $\mathrm{C}$, especially phosphatases and leucine arylamidase. No significant correlations were found between soil chemical properties and glycosyl hydrolases. A considerable number of significant correlations were found among the enzymes. The relationships with $\mathrm{SOM}, \mathrm{N}$, respiration rate, microbial biomass $\mathrm{C}$ and enzymatic activities (Table 6) clearly indicate the beneficial effects of a good soil quality on biological activity.

In order to know the influence of the micro-method test on soil sample classification, a hierarchical test was carried out with enzymatic activities only (Figure 1). The dendogram obtained indicates a clear separation between the mollic Leptosols C1,

Table 6 Correlation coefficients from Spearman correlation matrix

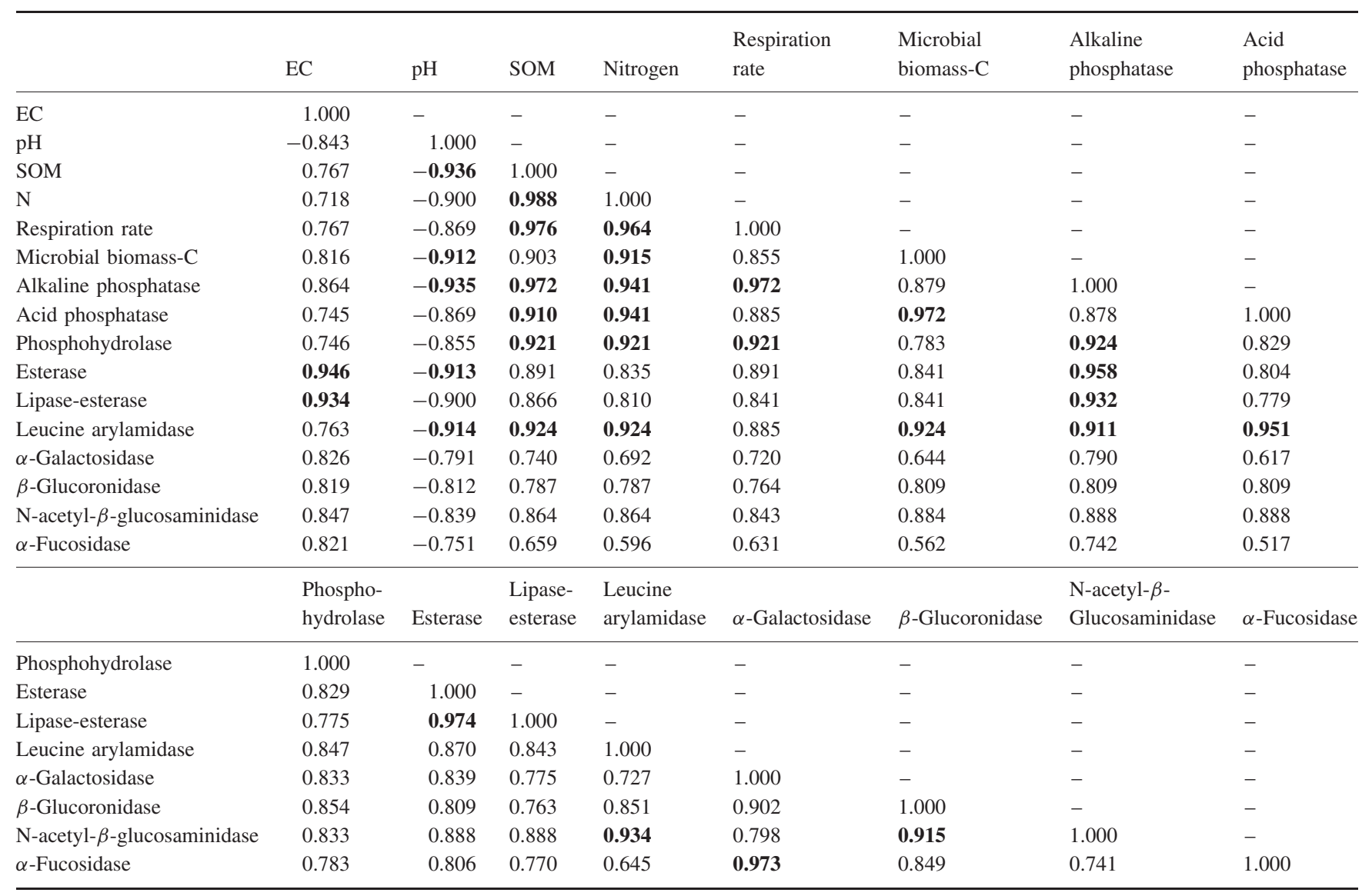

EC, electric conductivity; SOM, soil organic matter.

For valine arylamidase, $\alpha$-glucosidase, $\beta$-glucosidase and $\beta$-galactosidase, no significant correlation was found.

Significance with Bonferroni's adjustment with $P$-value $<0.050$; variables $=20$, significance values at $P<0.05$ are highlighted in bold type. 


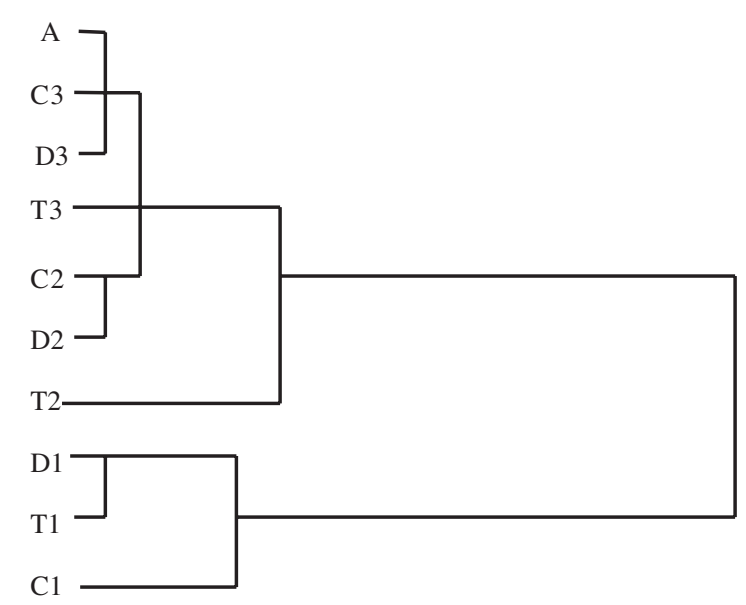

Figure 1 Hierarchical classification of soil samples using the enzymatic activity values. C1 and D1, mollic Leptosols; T1, rendzic Leptosol; T2 and T3, calcaric Regosols; D2, C2, D3 and C3, haplic Leptosols; A, albic Arenosol; 1, forest; 2, shrub-land; 3, farm.

D1 and rendzic Leptosol T1, and the haplic Leptosols C2, D2, C3, D3 and calcaric Regosols T2, T3. Figure 1 also depicts the differences found between farm soils and shrub-land soils in the case of T2 and T3, which clearly demonstrate the effectiveness of our method to distinguish between different soil types. Very similar results were obtained when this test was employed with all the soil characteristics studied (data not shown).

\section{Discussion}

The main reasons for measuring soil enzymatic activities as soil quality indicators are the following: (i) enzymatic activities are useful as biosensors for soil quality assessments; (ii) they relate very closely to properties indicating soil degradation such as SOM, physical properties, microbial activity or the amount of biomass; (iii) they are an earlier indicator of soil quality development and of the changes taking place than other characteristics; and (iv) they can provide information about the past history of the soil.

\section{Influence of soil formation factors on soil characteristics}

In the study area, soil formation factors, including human activities, influence soil attributes and soil quality. The Mediterranean climate (the meso-Mediterranean and supra-Mediterranean bioclimatic belts) and the calcareous parent materials (limestone, dolomite, marl and sands) from the principal source influence directly the soil physical and chemical characteristics. Soil quality is defined not only in terms of its productive capacity, but also because of its ecological functions. Thus, even when soil productivity has to be maximised, detrimental environmental effects must be kept to a minimum (Doran \& Parkin, 1994). It is evident that the changes in soil quality caused by different land-use types must firstly be quantified to establish those that are the most sustainable. Then the best management to disturb the soil least has to be determined taking into account physical, chemical, biological and biochemical properties, changes in which will influence changes in soil quality (Trasar-Cepeda et al., 2008). The results obtained in our study indicate that human activity, such as deforestation and agricultural use, leads to negative changes in soil attributes. Because of these effects, changes in the morphological characteristics of the soil profile occur; the O-horizon disappears, and the mollic A-horizon changes into an ocric diagnostic horizon in shrub-land communities and into an anthropic diagnostic horizon under many agricultural practices. These changes also bring about variations in some soil properties; for instance, less SOM, and increased soil $\mathrm{pH}$ and calcic carbonate content (Table 2). These facts are very important for the purposes of our study because they relate to soil biology and biochemistry and indicate that there is much soil biological activity in the Ah-horizons of mollic Leptosols, which enhances extracellular enzymatic activities.

\section{Soil quality, and biological and biochemical parameters}

Soil biological and biochemical properties respond rapidly to changes (Nannipieri et al., 2003), and include those that relate directly to the number and activity of soil microbiota. Enzymes respond immediately to changes in the soil fertility status, and can be used as potential soil quality indicators for sustainable management purposes (Caldwell, 2005; Alotaibi \& Schoenau, 2011; Wallenius et al., 2011).

Our study suggests that the loss of a soil quality sequence is related to land use (Table 1), as demonstrated by the loss of the organic horizon in the soil profile. This change contributes to decreased SOM, N contents, microbial biomass $\mathrm{C}$ and respiration rate (Table 2), all of which imply reduced soil quality. From this, the soil quality sequence is: mollic Leptosols $>$ rendzic Leptosols $>$ haplic Leptosols $>$ calcaric Regosols > albic Arenosols. Soil biochemistry is related intimately to these factors and as demonstrated by our new approach the intensity and the number of active enzymes are as expected in relation to the sequence of soil quality as demonstrated earlier (Table 5).

Our data demonstrate that enzyme activities are a result of these soil changes (Table 5). Thus, phosphatase enzymes such as alkaline phosphatase, acid phosphatase and phosphohydrolase have good activity in mollic and rendzic Leptosols, and decrease considerably in haplic Leptosols, calcaric Regosols and albic Arenosols. Phosphatases are crucial in P transformation and these activities are greatly influenced by soil use and the inorganic $\mathrm{P}$ added to the soil (Bastida et al., 2008; Trasar-Cepeda et al., 2008; Fioretto et al., 2009). Similar results have been obtained by Fioretto et al. (2009), who analysed the soil enzyme activities involved in the main element cycles and the soil ATP content at earlier serial stages (meadow, low shrub-land and high maquis) of the Mediterranean ecosystem.

Amino peptidases such as leucine aryl amidase and valine amidase, esterases such as esterase and lipase-esterase, and glycosyl hydrolases such as $\alpha$-galactosidase, $\beta$-galactosidase, $\beta$-glucoronidase, $\alpha$-glucosidase, $\beta$-glucosidase and $\mathrm{N}$-acetyl- $\beta$ glucosaminidase, present in the API ZYM strips, show the 
same pattern as the phosphatases. These enzymes are important for the mineralization of organic $\mathrm{N}$ and $\mathrm{C}$. For example, $\beta$ glucosaminidase activity may provide information about soil quality in semi-arid environments because it is a key enzyme involved in the hydrolysis of the $\mathrm{N}$-acetyl- $\beta$-d-glucosamine residue from the terminal non-reducing ends of oligosaccharides and is important for $\mathrm{C}$ and $\mathrm{N}$ cycling processes (Ekenler \& Tabatabai, 2002). As reported by Sardans et al. (2008) for a Spanish shrub-land, $\beta$-glucosidase activity correlates positively with some soil quality indicators. In line with all these results, our data confirm generally reduced soil enzyme activity after soil degradation processes under Mediterranean conditions.

Our results also suggest that of the variations taking place in the biological soil properties because of the loss of plant cover, SOM and $\mathrm{N}$ are good indicators of soil quality and relate to the loss of basic ecological functions. They also indicate that the tested enzyme activity patterns were dependent on the soil properties considered in this study. Furthermore, when the mean values for the 10 soil samples are considered, the mollic and rendzic Leptosols influenced by Holm oakwoods tend to have greater relative activities for most enzymes when compared with the haplic Leptosols and calcaric Regosols in shrub- and managed land (Table 5).

Other important enzymatic activities include those of dehydrogenase, which has been used as an indicator of viable microorganisms and arylsulphatase, which catalyses the hydrolysis of sulphate ester bonds and has its activity positively affected by the addition of organic matter. These enzymes are not included in the API strip used. However, of the 19 enzymes determined, except for lipase, cystine aryl-amidase, trypsin, $\alpha$-chymotripsin and $\alpha$-mannosidase, all have provided effective information to assess the differences in the soils studied.

\section{Conclusions}

Soil quality cannot be defined from a simple monitoring determination. From our study, we are able to conclude that the API ZYM method could prove a rapid, useful method to study soil biochemical properties and that it can be easily used in a cost-effective way. We are currently testing the micro-method with other soil types and at different sites. Biological variables are most valuable as early, sensitive indicators of changes in soil properties induced by different soil quality status. Managed soils and the supporting degraded vegetation clearly have smaller SOM contents, $\mathrm{N}$ contents, respiration rates, microbial biomass $\mathrm{C}$ and enzyme activities. Phosphatases, esterase, lipase-esterase, leucine arylamidase, $\alpha$-galactosidase, $\beta$-galactosidase, $\beta$-glucoronidase, $\beta$-glucosidase and $\mathrm{N}$-acetyl- $\beta$-glucosaminidase activities were detected in forest soils at large rates, suggesting an enrichment process of the hydrolytic enzymes in organic matter and nitrogen, and show effectively the use of enzymes as indicators of changes in the soil environment and soil quality. This complexity prevents an accurate selection of the best enzyme or enzymes to be used as key indicators, at least until more is known about the processes resulting from land-use changes. API ZYM is a multi-variable monitoring method capable of providing useful information on the soils studied in this work. We believe that future studies are required in other areas and with other soil types to extend these results and to investigate other possibilities for employing this micro-method as an indicator of soil change and quality. Other enzymes such as dehydrogenase, arylsulphatase or urease included in other API strips could be assessed in other experiments because they could also prove to be good indicators of soil microbial activity and soil quality.

Finally, we suggest that the data shown in this paper will be an important step forward in developing an enzyme test that is fast and very easy to apply and will aid other groups researching soil quality.

\section{Acknowledgement}

The research described in this paper has been supported by projects from the Spanish Ministry of Innovation and Science (CGL2006-09776 and AGL2011-29382). The authors would like to thank Professor Mario Sendra (Statistic Department, Universitat de València) for his assistance in the statistical analysis.

\section{References}

Adrover, M., Farrús, E., Moya, G. \& Vadell, J. 2012. Chemical properties and biological activity in soils of Mallorca following twenty years of treated wastewater irrigation. Journal of Environmental Management, 95, 188-192.

Alotaibi, K.D. \& Schoenau, J.J. 2011. Enzymatic activity and microbial biomass in soil amended with biofuel production by products. Applied Soil Ecology, 48, 227-235.

Bastida, F., Zsolnay, A., Hernández, T. \& García, C. 2008. Past, present and future of soil quality indices: a biological perspective. Geoderma, 147, 159-171.

Bidochka, M.J., Burke, S. \& Ng, L. 1999. Extracellular hydrolytic enzymes in the fungal genus Verticillium: adaptations for pathogenesis. Canadian Journal of Microbiology, 45, 856-864.

Blum, W.E.H. 1990. The challenge of soil protection in Europe. Environmental Conservation, 17, 72-74.

Caldwell, B.A. 2005. Enzyme activities as a component of soil biodiversity: a review. Pedobiologia, 49, 637-644.

Cornforth, I.S. 1999. Selecting indicators for assessing sustainable land management. Journal of Environmental Management, 56, 173-179.

Day, P.R. 1965. Particle fractionation and particle-size analysis. In: Methods of Soil Analysis. Part I (ed C.A. Black), pp. 545-567. American Society of Agronomy, Madison, WI.

Doran, J.W. \& Parkin, T.B. 1994. Defining and assessing soil quality. In: Defining Soil Quality for a Sustainable Environment (eds J.W. Doran, D.C. Coleman \& D.F. Bezdicek), Special Publication 35, pp. 3-21. Soil Science Society of America, Inc. \& American Society of Agronomy, Inc., Madison, WI.

Doran, J.W., Sarrantonio, M. \& Liebig, M.A. 1996. Soil health and sustainability. Advances in Agronomy, 56, 1-54.

Ekenler, M. \& Tabatabai, M.A. 2002. Beta-glucosaminidase activity of soils: effect of cropping systems and its relationship to nitrogen mineralization. Biology \& Fertility of Soils, 36, 367-376. 
FAO 2006. World Reference Base for Soil Resources 2006. A Framework for International Classification, Correlation and Communication. World Soil Resources Report No 103, FAO, Rome.

Fioretto, A., Papa, S., Pellegrino, A. \& Ferrigno, A. 2009. Microbial activities in soils of a Mediterranean ecosystem in different successional stages. Soil Biology \& Biochemistry, 41, 2061-2068.

Floch, C., Capowiez, Y. \& Criquet, S. 2009. Enzyme activities in apple orchard agroecosystems: how are they affected by management strategy and soil properties? Soil Biology \& Biochemistry, 41, 61-68.

Garcia-Martos, P., Marin, P., Hernandez-Molina, J.M., Garcia-Agudo, L., Aoufi, S. \& Mira, J. 2001. Extracellular enzymatic activity in 11 Cryptococcus species. Mycopathologia, 150, 1-4.

García-Ruíz, R., Ochoa, V., Hinojosa, M.B. \& Carreira, J.A. 2008. Suitability of enzyme activities for the monitoring of soil quality improvement in organic agricultural systems. Soil Biology \& Biochemistry, 40, 2137-2145.

ISO 1994a. ISO 11464. Soil Quality. Pre-treatment of Samples for Physicochemical Analysis. International Organization for Standardization, Geneva.

ISO 1994b. ISO 10390. Soil Quality. Determination of $\mathrm{pH}$. International Organization for Standardization, Geneva.

ISO 1994c. ISO 11265. Soil Quality. Determination of the Specific Electrical Conductivity. International Organization for Standardization, Geneva.

ISO 1995. ISO 10693. ISO 11265. Soil Quality. Determination of Carbonate Content. Volumetric Method. International Organization for Standardization, Geneva.

ISO 1997. ISO 14240-1. Soil Quality. Determination of Soil Microbial Biomass. Part 1: Substrate-induced Respiration Method. International Organization for Standardization, Geneva.

Jain, P.C., Lacey, J. \& Stevens, L. 1991. Use of API-ZYM strips and 4-nitrophenyl substrates to detect and quantify hydrolytic enzymes in media and grain colonized with Aspergillus, Eurotium and Penicillium species. Mycological Research, 95, 834-842.

Karlen, D.L., Mausbach, M.J., Doran, J.W., Cline, R.G., Harris, R.F. \& Schuman, G.E. 1997. Soil quality: a concept, definition, and framework for evaluation. Soil Science Society of America Journal, 61, 4-10.

Khan, A.R., Khazanovich-Bernstein, N., Bergmann, E.M. \& James, M.N.G. 1999. Structural aspects of activation pathways of aspartic protease zymogens and viral $3 \mathrm{C}$ protease precursors. Proceedings of the National Academy of Sciences of the United States of America, 96, 10968-10975.

Macci, C., Doni, S., Peruzzi, E., Masciandaro, G., Mennone, C. \& Ceccanti, B. 2012. Almond tree and organic fertilization for soil quality improvement in southern Italy. Journal of Environmental Management, 95, S215-S222.

Nannipieri, P., Ascher, J., Ceccherini, M.T., Landi, L., Pietramellara, G. \& Renella, G. 2003. Microbial diversity and soil functions. European Journal of Soil Science, 54, 655-670.
Pérez-de-Mora, A., Madejón, E., Cabrera, F., Buegger, F., Fuß, R., Pritsch, K. et al. 2008. Long-term impact of acid resin waste deposits on soil quality of forest areas II. Biological indicators. Science of the Total Environment, 406, 99-107.

Platen, H. \& Wirtz, A. 1999. Applications of analysis $\mathrm{N}^{\circ} 1$; Measurement of the respiration activity of soils using the Oxitop ${ }^{R}$ control measuring system. Basic Principles and Process Characteristic Quantities. Fachhochschule, Giessen-Friedberg, Germany.

Salazar, S., Sánchez, L.E., Alvarez, J., Valverde, A., Galindo, P., Igual, J.M. et al. 2011. Correlation among soil enzyme activities under different forest system management practiques. Ecological Engineering, 37, 1123-1131.

Sardans, J., Penuelas, J. \& Estiarte, M. 2008. Changes in soil enzymes related to $\mathrm{C}$ and $\mathrm{N}$ cycle and in soil $\mathrm{C}$ and $\mathrm{N}$ content under prolonged warming and drought in a Mediterranean shrubland. Applied Soil Ecology, 39, 223-235.

Serrano, A., Tejada, M., Gallego, M. \& Gonzalez, J.L. 2009. Evaluation of soil biological activity after a diesel fuel spill. Science of the Total Environment, 407, 4056-4061.

Thavamani, P., Malik, S., Beer, M., Megharaj, M. \& Naidu, R. 2012. Microbial activity and diversity in long-term mixed contaminated soils with respect to polyaromatic hydrocarbons and heavy metals. Journal of Environmental Management, 99, 10-17.

Tiquia, S.M. 2002. Evolution of extracellular enzyme activities during manure composting. Journal of Applied Microbiology, 92, 764-775.

Tiquia, S.M., Wan, J.H.C. \& Tam, N.F.Y. 2001. Extracellular enzyme profiles during co-composting of poultry manure and yard trimmings. Process Biochemistry, 36, 813-820.

Trasar-Cepeda, C., Leirós, M.C. \& Gil-Sotres, F. 2008. Hydrolytic enzyme activities in agricultural and forest soils. Some implications for their use as indicators of soil quality. Soil Biology \& Biochemistry, 40, 2146-2155.

Walkley, A. \& Black, I.A. 1934. An examination of Degtjareff method for determining soil organic matter, and a proposed modification of the chromic acid titration method. Soil Science, 37, 29-38.

Wallenius, K., Rita, H., Mikkonen, A., Lappi, K., Lindström, K., Hartikainen, H. et al. 2011. Effects of land use on the level, variation and spatial structure of soil enzyme activities and bacterial communities. Soil Biology \& Biochemistry, 43, 1464-1473.

Wang, C., Guo, P., Han, G., Feng, X., Zhang, P. \& Tian, X. 2010. Effect of simulated acid rain on the litter decomposition of Quercus acutissima and Pinus massoniana in forest soil microcosms and the relationship with soil enzyme activities. Science of the Total Environment, $\mathbf{4 0 8 ,}$ 2706-2713.

Yu, C.C., Quinn, J.T., Dufournaud, C.M., Harrington, J.J., Rogers, P.P. \& Lohani, B.N. 1998. Effective dimensionality of environmental indicators: a principal component analysis with bootstrap confidence intervals. Journal of Environmental Management, 53, 101-119. 